\title{
ACCEPTABILITY AND EFFECTIVENESS OF MELC-BASED SUPPLEMENTARY LEARNING MATERIALS IN PHYSICAL EDUCATION 9
}

\author{
Jeffrey A. Castillo, LPT
}

Article DOI: https://doi.org/10.36713/epra7331

DOI No: 10.36713/epra7331

\begin{abstract}
This study answered the following questions: (1) What is the level of acceptability of the materials in terms of: (a) content; (b) objectives; (c) topics; and (d) activities?; (2) What are the mean scores of students in terms of pretest and posttest?; (3) Is there a significant difference between the pre-test and post-test mean scores? The study was conducted to prove that there was a significant difference in the pre-test and post-test among the respondents. The respondents of the study were composed of three (4) sections at Sampaguita Village National High School to test the effectiveness of using MELC-based Supplementary Learning Materials in Physical Education 9. In this study, random sampling method was used in choosing the respondents. The researcher made questionnaires validated by different experts from the same school where the study was conducted in the District of San Pedro, Schools Division of Laguna. Based on the data presented and interpreted in Chapter 4, the overall statistical data revealed that (1) The Level of Acceptability of Supplementary Learning Materials in Terms of Content, Objectives, Topics and Activities as perceived by the students was "Highly Acceptable". (2) During the pretest stage, the overall interpretation was Fairly Satisfactory; (3) During the posttest stage, the overall interpretation was Very Satisfactory; and (4) For the difference between the pretest and posttest it was found out that the mean difference between the pre-test and post-test of section Emerald was 3.30 with a t-value of 16.732 and p-value of 0.000 and with an analysis of Significant. For section Jade, the mean difference was 3.43 with a t-value of 16.997 and p-value of 0.000 and with an analysis of Significant. For section Jasper, the mean difference was 1.47 with a t-value of 16.323 and a p-value of 0.000 and with an analysis of Significant. For section Sunstone, the mean difference was 4.94 with a t-value of 26.876 and a p-value of 0.000 and with an analysis of Significant. Based on the findings, the following were conclusions derived from the data and results of the study presented, analyzed, and interpreted: (1) The MELC-based Supplementary Learning Materials had very effective contents, objectives, topics, and activities; (2) The students showed improved achievement after using MELC-based Supplementary Learning Materials; (3) The MELC-based Supplementary Learning Materials was an effective tool in teaching Physical Education during the new normal; (4) The Performance Level in Pretest of sections Emerald, Jade, Jasper and Sunstone was considered deficient before using the MELC-based Supplementary Learning Materials; (5) The Level of Performance in Posttest of sections Emerald, Jade, Jasper and Sunstone was described as Highly Acceptable. This meant that the use of MELC-based Supplementary Learning Materials helps the students in understanding the lessons in Physical Education based on the most essential learning competencies provided by the Department of Education; (6) There were overall significant difference in the result of the pretest and posttest using MELC-based Supplementary Learning Materials in Physical Education. The overall result in this study was highly significant; and (7) During the use of MELC-based Supplementary Learning Materials, the scores of the students were high showing that there was an improvement when it came to the learning outcomes of the respondents. Hence, the use of this MELC-based Supplementary Learning Materials was effective. Based on the conclusions formulated from the findings, the following recommendations were given; (1) For students' better academic performance, MELC-based Supplementary Learning Materials may be used as alternative mode learning delivery for students who are not capable of having high end gadgets for online modality. By using this, students need not go out of their houses in finding internet shops to search for the given activity instead the answers are incorporated in the reading materials attached to the supplementary learning materials; (2) Teachers may adopt this MELC-based Supplementary Learning Materials in handling students under Modular Distance Learning (MDL); (3) The School Administrators may provide allotted budget to produce these MELC-based Supplementary Learning Materials for students who are under Modular Distance Learning (MDL); (4) School Administrators may conduct seminars to assist teachers and make this kind of learning materials suited for each type of learners; and (5) Future Researcher may use this study to help improve the production of learning materials aligned in the New Normal Set Up of Education due to pandemic.
\end{abstract}

INDEX TERMS: MELC (Most Essential Learning Competencies), Supplementary Learning Materials, Pretest, Posttest, and Activities. 


\section{EPRA International Journal of Research and Development (IJRD)}

\section{INTRODUCTION}

\subsection{Overview}

Normal face-to-face interaction between teachers and students has been suspended due to the COVID-19 pandemic. This pandemic has paved the way to the implementation of Modular Distance Learning as an urgent response to ensure continuity of education here in the country. Our country as of this moment is in the process of adapting to the new normal form of education and continuous innovations of educators and active involvement of other stakeholders are the driving force for its success (Dangle \& Sumaoang, 2020). The teacher takes the responsibility of monitoring the progress of the learners. The learners may ask assistance from the teacher via e-email, telephone, text message/instant messaging, among others. Where possible, the teacher shall do home visitations to learners needing remediation or assistance (Llego, n.d.). Printed Modules and Supplementary Learning Materials will be delivered to students, parents, or guardians by the teachers or through the Local Government Units. But not all students who are now enrolled in the new normal set up education have the capacity to easily engage with the lessons written in the printed modules specifically, the video links which are not applicable to those students under Modular Distance Learning. This is the main problem why the researcher designed this kind of research to help the students under Modular Distance Learning. Therefore, this endeavor was conducted to offer solutions in improving the academic achievement of students in physical education during this time of new normal set up of education. The researcher would like to introduce the use of MELC- Based Supplementary Learning Materials as strategy in teaching physical education lessons based on the most essential learning competencies given by the Department of Education (DepEd). Supplementary materials help to motivate the learners (Dodd, 2015) by creating interests in learning and encouraging them to use the language in the class. They enable the learners to understand and grasp the information from a given text. The aim of Supplementary Learning Materials is to make students master the competencies based on the given most essential learning competencies prepared by the Department of Education (DepEd) for physical education. In doing so, once they mastered the concept, they could easily comprehend questions and answer the correctly, thus, better academic gain is achieved.

\subsection{Problems}

It sought to answer the following research problems: (1) What is the level of acceptability of the materials in terms of: (a) content; (b) objectives; (c) topics; and (d) activities?; (2) What are the mean scores of students in terms of pretest and posttest?; (3) Is there a significant difference between the pre-test and post-test mean scores?

\subsection{Importance of the Problem}

This research study is essential because it focused on the acceptability and effectiveness of using Supplementary Learning Materials in Physical Education 9 in the new normal.

\subsection{Literature}

As cited by Kuehn (2017), the pretest and posttest can be a valuable diagnostic tool for more effective teaching. It should be designed to measure the amount of learning a student has acquired in a specific subject. To do this, questions concerning all the topics covered during the quarter must appear on the test. To demonstrate the student progress has been made during the given quarter, the posttest score should be higher than the pretest score. Goldman (2014) emphasizes that the pretest and posttest are the quantifying of the knowledge attained in the class from a group of students with diverse learning styles and educational backgrounds. Corresponding to this, Danielson (2017) states that the summative evaluation flags the finish of a showing scene as a method of revealing the understudies' accomplishment in the instructing - learning procedure will exclusively depend on understudy cooperation during study hall conversation. In addition, Morisson (2010), said that evaluation is fundamental since it is the place all choice the instructor is going to make will originate from. Evaluation choices will coordinate and change understudies' learning results. If evaluations are utilized properly, understudies will unquestionably learn well. It ought to be intended to a particular reason and ought to be solid, legitimate, and reasonable. Surgenor (2010), emphasized that there are jobs of evaluation. Appraisal catches understudy's time and consideration, it produces suitable understudy learning action, it gives auspicious criticism which understudies focus, it causes understudies to disguise uniformity, it empowers the educators in choosing whether an understudy passed or fizzled, and it gives proof that principles in the subject is proper. As indicated by Jones (2010), an appraisal as a major aspect of study hall exercises is a key procedure required to advance learning and at last accomplishment. Evaluation for learning is tied in with advising students regarding their advancement to enable them to make the fundamental move to improve their exhibition. Instructors need to make learning openings where students can advance at their own pace and embrace solidification exercises were fundamental. Acero (2017), articulates that activities are kind of formative assessment to improve the conveyance of guidance inside the study hall. This is regularly the strategy for quality control. It is delineated to see whether needs are there int he handles of guidance with the goal that indispensable modification can be made for success. Mouly (2015) emphasizes the connotation of pre-test as a test given to measure the outcome of variable before the experimental manipulation is implemented. A pre-test is followed by a posttest, which is the same test as a pre-test, after the experimental manipulation has been implemented. This pre-test and posttest design allowed the experimenter to test what effect if any, the experimental manipulation had been assessing the differences in the pretest and posttest. If there are any differences, it is likely to be due to manipulation by the researcher either action or experimental mental of investigation. In the study of Ely (2012), it is stated that the foregoing view upon disclosure that after the discussion method utilized by teachers in the classroom, a pretest must be given to students in order to determine as to whether or not 


\section{EPRA International Journal of Research and Development (IJRD)}

they learn by thinking and talking together as a group through the group process as shared appreciation of the subject matter. Thus, a pretest is administered to determine the students baseline knowledge or preparedness for an educational experience or course of study. This must be done to assess the normality of students in acquiring creative thoughts by their own effort by making progress as a result of their own and others response to stimuli of questioning and volunteered expression during the class discussion. Marsden and Torgenson (2012) discuss the two illustrations of some of the factors that can influence findings from pre- and post-test research designs in evaluation studies, including regression to the mean (RTM), maturation, history and test effects. The first illustration involves a re-analysis of data from a study by Marsden, in which pre-test scores are plotted against gain scores to demonstrate RTM effects. The second illustration is a methodological review of single group, pre- and post-test research designs (pre-experiments) that evaluate causal relationships between intervention and outcome. As stated by Cole (2014), a pre-test of five to six students selected to study the topic in advance wherein each one of them must speak on some factors of the Science subject to the class and after which a general discussion follows to talks. In connection to this aside from managing and using the interests and energies of the learners promoting their own better learning, this method has a therapeutic function, important for real respect for others' sore spots and a greater involvement with the intellectual aspects of the topic under discussion. A parallel idea has been drawn by Dreeben (2014) that a pre-test must aim at determining students' baseline knowledge or preparedness for an educational experience most particularly when an organized small group discussion method is deployed in the classroom by a Science teacher. Most likely with this trending, maximum active student involvement is encouraged as well as interest in well-chosen topic for class discussion. Before a pre-test is given, time must be observed for a greater preparation of arguments when topics are specially challenging or require scientific technology information. This method is most valuable for teaching topics requiring series and thorough discussion which by all means call for a critical thinking and balanced arguments among students' participants. Based on the study of Acero (2007), exercises and activities are types of formative evaluation to improve the delivery of instruction in the classroom. This is the phase of evaluation where what the teacher does in the course of his teaching and what he is to do are given forms. This is the process of quality control. It is designed to examine whether deficiencies are there in the process of instruction so that necessary adjustment can be made for successful result. It is usually done in pilot stage or at any point in the various stages of instruction process. This will help not only to determine how much learning has been achieved through instruction but how to get rid of unintended outcomes if any. To this end it becomes a very important aspect of monitoring process. As stated by Lee (2005), exercises and activities from the "core" of the module set the input- processing of the output and input practice task sequence for each activity in turn. All in text questions self- assessment and feedback quizzes should be included as part of the sequence. Exercises and activities are done during the application of concepts to enable students master and improve their performance and be able to identify the content that are to be improved. Bucjan (2011) states that varied activities and techniques used in modules were helpful to the learners, and the tandem of teaching and learning was evident allowing the students to work independently, the modules were very relevant and very useful for the use in the class because these answers the need of the students. When we think of student engagement in learning activities, it is often convenient to understand engagement with an activity as being represented by good behavior (i.e., behavioral engagement), positive feelings (i.e. emotional engagement), and, above all, student thinking (i.e., cognitive engagement) (Fredricks, 2014). This is because students may be behaviorally and/or emotionally invested in a given activity without actually exerting the necessary mental effort to understand and master the knowledge, craft, or skill that the activity promotes. In light of this, research suggests that considering the following interrelated elements when designing and implementing learning activities may help increase student engagement behaviorally, emotionally, and cognitively, thereby positively affecting student learning and achievement:: (1) make it meaningful, (2) foster a sense of competence, (3) provide autonomy support, (4) embrace collaborative learning, (5) establish positive teacher-student relationships, and (6) promote mastery orientations. Moreover, as stated by Oliveira (2018), in many cases, pedagogical concepts are universal. However, practical application and development of activities need (very much!) to consider the context of the classes and students' locality. Regarding the teaching material, she used to adapt the tourist sites that appeared in the books to the reality of the children. Instead of talking about the Statue of Liberty, she would take newspaper and magazine clippings of tourist sites from our city, presenting our region before other places. Majault (2015) claims the fact that a posttest is a gauge to determine the outcome of the learning tasks of large classes when committee project method is deployed as instructional service delivery within the four walls of the classroom. With the results of the posttest, science teachers will be able to determine as to whether or not the committee project method aroused participation in the learning tasks of the greatest magnitude of students for them to take responsibility to think out problems for themselves and to take initiative in tackling them, and coupled with the development of cooperative work as well as individual initiative by fostering a sense of responsibility among members of class in their respective committees so created for projected realization. More than ever as rectified by Stabler (2014), a posttest is basically a most viable measure to determine the outcome after laboratory method has been deployed in learning science. With the end results, learning by doing is within the sphere of teacher's direction by providing learning situations at first hand for students to translate theory into practice, to develop, to test and apply principles, and to learn methods of procedure with greater reliance on their own power, and with extensive restrictions which group work often imposes on the individual learner with the end in view that at the end of the day, the 


\section{EPRA International Journal of Research and Development (IJRD)}

teacher has the chance to observe the students in action, assess their work, correct their mistakes, and give ample time to guide them in the correct direction in avoiding wastages of the human and material resources. The bibliographical sinews of Stiles (2014) give much teeth to posttest as a most valid and reliable measure to the learning outcome of students when exposed to programmed learning wherein the infusion of mechanical self-teaching contrivances are capable of representing a course of instruction based on a pre-planned program consisting of the facts the students have to learn and study. More than ever, the rest of the posttest are feedbacks offered to materialize the pedagogic design in the very sequence of the learning frames presented therein. Stinnett (2013) strengthens further the aforementioned viewpoints by noted authorities upon strong disclosure that posttest is a most valid and reliable measure structuring the instruction of information, the arrangement of optimum sequences for learning, and by reflecting a new concern with the efficient use of the latest informational technology in teaching-learning process. Natrella (2015) comes up with the point stressing out the vital importance of pretest and posttest as used to measure knowledge gained form participating in a training course. The pretest is a set of questions given to participants before the training begins in order to determine their knowledge level of the course content. After the completion of the course, participants are given the posttest to answer the same set of question, or a set of questions of comparable difficulty. Comparing participants' posttest scores to their pretest scores enables ones to see whether the training was successful in increasing the participants' knowledge of the training content. Thus, in retrospect as confirmed strongly by Wine (2015), all pretest and posttest must be validated before they are considered reliable data collection tool. If participants get a question wrong, it should be because of lack of knowledge, not because a participant interpreted the question differently than it was intended because the question was poorly written and had one more correct answer, or because the question addressed content was not taught in the course. Instructional materials have been observed as a powerful strategy to bring about effective teaching and learning. The importance of quality and adequate instructional materials in teaching and learning can occur through their effective utilization during classroom teaching. Instructional materials here include all the tools that the teachers can use to make the learning more interesting and memorable (Tety, 2016). Instructional materials are essential tools in learning every subject in the school curriculum. They allow the students to interact with words, symbols and ideas in ways that develop their abilities in reading, listening, solving, viewing, thinking, speaking, writing, using media and technology (Bukoye, 2019). According to Faize and Dahan (2011), instructional materials are print and non-print items that are designed to impact information to students in the educational process. Instructional materials include items such as prints, textbooks, magazines, newspapers, slides, pictures, workbooks, electronic media, among others. According to Raw (2010), the first instructional material is the textbook. Various definitions of textbook emphasize the role of textbook as tool for learning. Textbook is the nucleus to all the learning activities related to a particular curriculum. Textbook plays a vital role in imparting knowledge to the students in the third world countries. Instructional materials play a very important role in the teaching-learning process the availabilities of textbook, appropriate chalkboard, Mathematics kits, Science kit, teaching guide, science guide, audio-visual aids, overhead projector, among others are the important instructional materials (Yusuf, 2005), However many facilities are missing in approximately almost all secondary schools in the state. From Yusuf (2005) further says that, the next instructional materials are the chalkboards. The chalkboard is the teaching aid that teachers frequently used, particularly during the lectures and discussions. There are different kinds such as, blackboard, maker board, write board, felt board and magic board. The teachers use it in classrooms to write the important words, statement, to draw diagrams, figures, and maps. Other prominent instructional material includes mathematics kits. This is usually study kit; it is a box containing a variety of visual aids artistically assembles and displayed pertaining to a single topic (Nichollos, 2000). Omabe (2006) asserts that instructional materials are central in the teaching and learning of English language because they are used to compliment efficiency of a teacher, and effectiveness in lesson delivery. Esu, Enukoha and Umoren (2004) affirmed that instructional materials facilitate learning of abstract concepts by helping to concretize ideas and stimulate learners" imagination. Moreover, instructional materials help to increase active participation in the learning process while saving teacher's energy, reducing the teacher centeredness in teaching. In the same vein, Mathew (2012) states that the use of instructional materials make teaching effective as it enables learners to participate actively in classroom instruction. All these views suggest that the use of instructional materials can improved students" performance. Olumorin, Yusuf, Ajidagba and Jekayinfa (2010) also observe that instructional materials help teachers to teach conveniently and the learners to learn easily without stress. They assert that instructional materials have direct contact with all the sense organs of the students. Kochhar (2012) supports this view by saying that, instructional materials are very significant learning and teaching tools. He adds that there is need for teachers to find necessary and relevant instructional materials to complement classroom interaction and textbooks to broaden and arouse students" interests in the subject. Oluwagbohunmi and AbduRaheem (2014) acknowledge that instructional materials are such used by teachers to aid explanations and make learning of subject matter understandable to students during teaching learning process. Abdu-Raheem (2011) asserted that non availability and inadequacy of instructional materials are major causes of ineffectiveness of the school system and poor performance of students in schools. According to Abolade (2009), the advantages of instructional materials are that they are cheaper to produce, useful in teaching large number of students at a time, encourage learners to pay proper attention and enhance their interest. Isola (2010) also describes instructional materials as objects or devices that assist the teachers to present their lessons logically and sequentially to 


\section{EPRA International Journal of Research and Development (IJRD)}

the learners. Kochhar (2012) supports those instructional materials are very significant learning and teaching tools. He suggested the needs for teachers to find necessary materials for instruction to supplement what textbooks provide to broaden concepts and arouse students" interests in the subject. Afolabi and Adeleke (2010) identify non-availability, inadequacy and non-utilization of learning materials as a result of teacher's poor knowledge as factors responsible for the use of lecture method. They recommended that both the students, teachers, parents, Parents/Teacher Association, government and philanthropists should be involved in improvising instructional materials for the teaching and learning in schools. Ogbondah (2008) advocates for of teachers" resourcefulness and encouraged them to search for necessary instructional materials through local means to supplement or replace the standard ones. Oso (2011) also agrees that the best way for teachers to make use of their manipulative skills is to improvise to achieve their lesson objectives at least to a reasonable extent. Jekayinfa (2012) also identifies the importance of instructional materials as making learning concrete and real, substitutes one thing for another, allows the students to participate in the production of materials, economical and more teacher-student resource oriented. The Roles Played By Instructional Materials In TeachingLearning Activities: Instructional materials play a very important role in the teaching-learning processes which include; (1) enhance the memory level of the students; (2) facilitate the teaching- learning process; (3) improve of student rate of accumulation; (4) serve as tools used by the teachers to correct wrong impression and illustration things that, learners cannot forget easily; (5) assist in giving sense of reality to the body of knowledge under discussions; (6) give lessons a personal look and encourages teacher's creativity; and (7) permit the students and teachers to experience in concrete terms the learning activities that can promote the idea of self-evaluation (Bukoye, 2019). Weimer (2012) enumerates the five characteristics of a learner-centered teaching. According to her learner-centered teaching engages students in the hard, messy work of learning, includes explicit skill instruction, encourages students to reflect on what they are learning and how they are learning it, motivates students by giving them some control over learning processes, and encourages collaboration. This clearly requires that science teachers to maximize their creativity to explore different strategies and approaches for better learning and understanding of students of the difficult concepts in science. According to Legaspi (2014), the Department of Education agrees that there have been delays in the delivery of learning materials such as activity sheets and modules for the pupils. The lack of learning materials is a perennial issue even before the change of the curriculum. The shortage of instructional materials and also teachers' lack of knowledge on material development is a persisting problem among the public and private elementary schools. Although DepEd boldly declared that all learning material shortages will be wiped out before the end of 2013 and even promised to have a one is to one or 1:1 ratio for student to textbook within school year 2012 2013 , but in the actual classroom setting, one textbook is shared by two to three and even more pupils. According to Rodrigo (2015), reteaching the lessons which are not clear to the learners and help them gain mastery of the skills. The role of developing instructional and intervention materials in the teaching-learning process should not be undermined. It plays an integral role toward the achievement of a successful interplay of teaching and learning (Salviejo, et.al., 2014). As claimed by Olawale (2013), "the importance of Instructional Materials in any teaching learning process cannot be over emphasized." If properly prepared, these materials will be effective in terms of enhancing, facilitating, and making teaching learning easy, lively, and concrete. Moreover, the study of Anderson (2012) reveals that using intervention material had assisted the learners of Biology to improve their performance in understanding the concepts of photosynthesis, respiration, mendelian, and non-mendelian genetics. His use of computer-based materials and exercises on concept mapping allowed these students to improve their performance significantly in answering and understanding genetic problems and concepts. As cited by Quisumbing et.al. (2017), the development of effective instructional materials designed to enriched student learning. Teachers should begin by analyzing what the learner should know at the end of the course and how learning will be demonstrated. The teacher must have more knowledge and understanding of the learning process, particularly how individual learning. This will help them learn immensely in both the design and implementation of teaching that enhances learning (Sims \& Sims, 1995). It is essential that teachers learn how to identify the needs of their students and their own professional learning needs. They also need to develop the self- regulatory skills that will enable them to monitor and reflect on the effectiveness of the changes they make to their practice (Timperley, Wilson, Barrar \& Fung, 2008). Teachers provide opportunities for students to engage actively in meaningful communication, encourage them to take ownership of their own learning, and give them explicit instruction in the content and language skills they need and in strategies for gaining that knowledge skills they need and in strategies for gaining that knowledge and those skills (Peyton, Moore \& Young, 2010). For effective teaching and learning to take place, Adbu-Raheem (2011) suggests that improvisation of local and simple instructional materials by the teachers has become necessary for the uplift of academic standard. Teaching with relevant instructional materials is an exceptional one, going into any class without these materials is a problem on its own. In the teaching of computer science, instructional materials perform such functions as an additional to the series of experience available to learners, an add-on to the teacher's voice explanations thereby making learning experience better- off and providing the teacher with interest into an extensive variety of learning activities (Bawa, 2016). The importance of instructional materials in the development of learners' intellectual abilities and attainment of teaching/ learning objectives cannot be over-emphasized. The students taught with instructional materials have excellent achievement scores compared with those taught without any material (Olayinka, 2016). Ball (2018) states that most people would agree that an understanding of content matters for teaching. 


\section{EPRA International Journal of Research and Development (IJRD)}

Yet, what constitutes understanding of the content is only loosely defined. In the mid-1980's, a major breakthrough initiated a new wave of interest in the conceptualization of teacher content knowledge. However, after two decades of work, this bridge between knowledge and practice was still inadequately understood and the coherent theoretical framework Shulmak (1986, p.9) called for remained undeveloped. This article builds on the promise of pedagogical content knowledge, reporting new progress on the nature of content knowledge for teaching. Although the term pedagogical content knowledge is widely used, its potential; has been only thinly developed. May seem to assume that its nature need, and content are obvious. Yet lacked definition and empirical foundation, limiting its usefulness. Frequently, for example, are broad claims about what teachers need to know. Such statements are often more normative than empirical. Only a few studies have tested whether there are, indeed, distinct bodies of identifiable content knowledge that matter for teaching. According to Wedger (2015), the objectives must be clear to students. They all must know what they are learning and why they are doing it. They also need to see the point of the objectives in the bigger picture; this is, how they relate to the last lesson's learning, the course they are following and the big overall goal. This means that one cannot simply write the objectives on the board and hope that the students copy them down. It implies that he/she has fully explained them in context; the students have engaged with them and can explain them to any observer. The objectives and outcomes must be differentiated for the individual student. All the learners should be able to see where they are and what they need to do to get to the next level. This should link into subject standards and progression where possible. It is crucial have high expectations of what can be achieved and engage the students with that belief. Success criteria for achieving the outcomes need to be negotiated with the students for optimum engagement to enable them to be clear about what it will look like and feel like and sound like when they have made that progress. In addition, a learning objective states specifically what a student should be able to do. In addition, Nic (2013) provides some examples of good learning objectives: Students will be able to: (1) identify different levels of data in new scenarios; (2) explain in context a confidence interval; (3) determine which probability distribution out of binomial, poisson or normal is most appropriate to model in unfamiliar situation; and (4) compare two tome series models of the same data and evaluate which is more appropriate in a given context. Nic also mentioned that learning objectives need to be specific and measurable. Some things that people might think are learning objectives but are not: (1) students will understand the central limit theorem, (The term "understand" is not measurable), (2) students will learn about probability trees ("learn" is not measurable and does not specify the level. Do students need to be able to interpret or create probability trees?). Nic also added that there are vast numbers of resources on learning objectives online. Learning objectives tell students what is important. Without learning objectives, it is difficult for students to know what they are supposed to be learning. In a lecture, a teacher can talk extensively about a case, but unless she states explicitly, it can be difficult for the students to know where to direct their attention. Do they need to know the details of that specific case or what principles they are supposed to glean from the example? Or was it just a "war-story" to entertain the troops? Students can waste a great deal of time studying things that are not necessary, to the detriment of their learning as a whole. The uncertainty also causes unnecessary anxiety. Learning objectives enable good assessment development. If they found it difficult to write a question to assess a learning objective, then they would think again about the learning objective, and what it is they really want the students to be able to do. It made it easier to write fair, comprehensive assessment. Everette (2017) states that no matter what standards teachers use, there is a constant in every lesson: the learning objective. Objectives are the basis of what one hopes to accomplish in any given lesson. A more powerful term, Student Learning Objectives (SLOs), are specific learning goal coupled with a specific way of to measure where students are in meeting that goal. SLOs can be large and meaty goals that teachers aim to meet over the course of a year of instruction, but mini-SLOs can happen each and every day in class. Everette adds that, there are many teachers who will say they write the objective on the board each day but see no real purpose or gain. "It is just one of those things we are told to do, so we do," a teacher told the researcher recently. The objective should be more than a check sheet item for teachers to satisfy administrators. So what should an objective do? (1) objectives focus the purpose of your lesson and subsequent planning, (2) objectives give you an outcome or goal, (3) objectives are smaller and more digestible than a full standard, (4) objectives can help students understand the lesson purpose, (5) combined with success criteria, objectives let you know when learning has happened and (6) objectives set the foundation for student-led academic discussion. According to Ravaglia (2020), typically, teacher development programmes tend to focus on enhancing pedagogy and classroom teaching skills and developing trendy 21 st-century skills such as creativity and collaboration. Too often, teacher trainers forget that expert knowledge of a subject is as important as expert knowledge of how to teach. Teaching is, after all a process of interaction between teacher, student and subject matter. Effective teaching requires teachers to possess detailed subject matter knowledge intertwined with knowledge of pedagogy, curriculum, student behavior, learning objectives and outcomes. Unfortunately, most teachers lack adequate subject matter knowledge (SMK) and curiously this lacuna is tolerated by most Indian schools. However, although SMK is a necessary skill, per se it's insufficient for a teacher. But conversely there's no guarantee that a teacher with SMK will be effective because of the other intertwined pedagogical requisites of effective teaching. Sadly, the opportunities teachers have to self-learn are uneven and inadequate, as they are products of the same system. It is thus imperative that teachers stay ahead of their students by continual exposure to subject material that is deeper than what they are expected to teach. Without continuous learning, they run the risk of precocious students posing baffling questions which embarrass teachers and undermine their authority in the 


\section{EPRA International Journal of Research and Development (IJRD)}

classroom. In addition, a good SMK development programme incorporated into teachers daily regimen is the educational equivalent of an effective physical fitness programme. It should be woven into the professional lives of teachers throughout the academic year. It helps to continually measure teachers SMK and enables use of analytics to fill gaps or advance teachers. The single most important feature of an SMK programme is that it is a rich bouquet of high-quality problem-solving questions and solutions which exposes teachers to a wide variety of nuanced concepts and principles in their prime subjects. This is entirely in keeping with the tenets of learning through problem-solving. According to Richards (n.d.), an activity describes any procedures in which learners work towards a goal such as play a game or engaging in a discussion. Secton, et.al. (2011), states that acceptability refers to a multi-faced construct on how people delivered or received a healthcare intervention, and considered it appropriate, based on anticipated or experienced cognitive and emotional responses in the intervention. As cited by Aguin (2011) in his study, the content of instructional materials and the way the content are presented, developed, and managed determine what kind of behavior will be shown by the learners. Andresen and Gronau (2010) describes adaptability as a feature of a system or of a process. This word has been used as a specialized term in different disciplines. The concept of adaptability has been widely recognized as a research field in recent years. Adaptability on a technical research field has been established in the last ten years. Adaptability is also understood as the ability of a system to adapt itself and fast to change circumstances. An adaptive system is therefore an open system that can fit its behavior according to changes in its environment. According to McTighe (2016), preassessments are the instruments or methods teachers use to determine students' knowledge, skills, or dispositions before instruction. Theoretically, pre-assessments help teachers determine where to begin instruction and provide teachers with baseline data from which to plot students' learning progress. Some pre-assessments are broad, addressing gradelevel or course learning goals, and are administered at the beginning of an academic year or semester. Others are narrower in scope and are administered at the start of a specific unit, focusing on that unit's learning targets. Some advocates even recommend using pre-assessments at the beginning of every lesson. Likewise, Guskey, T. et.al. (2018), conclude that teachers can design pre-assessments to measure any type of learning goal: cognitive, affective, or behavioral. Cognitive pre-assessments address academic goals and focus on what students know and can do. For instance, a teacher may ask what students remember from a previous lesson or pose an initial question such as, "Why is it warm in summer and cold in winter?" Cognitive pre-assessments are the most common form used in classrooms today. According to Hale (2018), it is very important to have a pre- test for questionnaire. The main concern of pre- test is to have a reliable question format and also a good wording and other. By establishing a correct pre- test, the questionnaire will yield better results. Kuehn (2019), also mentions that pre/post-test functions as a teacher diagnostic tool in the following five ways: (1) It Identifies the Very Weak Students in a Class; (2) It Identifies the strongest students in a class; (3) It identifies topics which the students already know; (4) It identifies topics which the students don't know; and (5) It identifies topics which the students have not learned. According to Fancher (2013) pretest-posttest designs are very common in scientific study. A characteristic common to true pretest-posttest designs is that two or more measurements are taken on each experimental unit. Subjects within each group receive a treatment of interest, no treatment, or a neutral treatment. Ideally, these experiments have a completely randomized design, whereby subjects are randomly assigned to the different levels of treatment. Through randomization, the effects of extraneous variables should be removed. Once the subjects are assigned to the groups, but before the actual treatment (if any) begins, each subject is measured on some characteristic to obtain his or her "Pretest" score. After the experiment has commenced, each subject is measured again one or more times to obtain his or her "Posttest" score or scores. When there are a number of such measurements taken at set periods of times for each subject, this is called a longitudinal or repeated measures study. Bhat (2012) states that instructional material is one of the valuable devices in the process of learning, there should be suitable supplementary materials for students so that they learn accordingly with the help of such learning materials. Macarandang (2009) suggests that the use of original self-instructional materials is particularly beneficial as a strategy in introducing basic information to an entire class, freeing the lecture discussion hours for more "discussions" and less "lecture", an enrichment activity for talented students; a strategy to make- up for a student who has been absent and a strategy for a student in need of remedial lectures. According to Hibek, J. (2015), Instructional Material is used as remediation materials by students who cannot cope up to their lessons, it comprises topics, discussions, and visual contents that give additional information relatively to specific lecture. Modules associated with images, and text are essentially usually having videos to complete the packages, and increase students understanding that may improve his/her skills and ability by their own. According Churchill (2013), Toch (2011), Wiggins \& McTighe (2008) as cited by Orosco (2020), traditional assessments are limited in that they only provide a narrow view of student recall and they may not accurately reflect what students.

\subsection{Time and Place of the Study}

The study was started at the beginning of the Second Grading of School Year 2020-2021 and finished at the end of the same grading period in Sampaguita Village National High School, District of San Pedro, Division of Laguna.

\section{METHODOLOGY}

The quasi- experimental design was used to determine the effectiveness of using MELC- Based Supplementary Learning Materials to students' academic performance in physical education from four (4) sections selected to be the respondents in this study. Quasi-experimental Design was 


\section{EPRA International Journal of Research and Development (IJRD)}

used because no randomization that happened in the formation of sections as participants of the study. Since the students had been grouped already by section before the start of experimentation, thus, could be regrouped. One hundred Twenty (120) grade 9 students were used as respondents in this research study. They were composed of four (4) sections already grouped/ sectioned before the study was made. Thirty (30) randomly selected respondents came from Grade 9Emerald, Jade, Jasper and Sunstone within Sampaguita Village National High School categorized as one of the big schools in the District of San Pedro, Schools Division of Laguna. Random Sampling Technique was used by the researcher in this study. Sections under Modular Distance Learning (MDL) were chosen as participants in this study. They were the group of students who needed most intervention to cope with the physical education lessons in this new normal set- up of education. The scores in the pre- test, worksheet and post-test were the primary sources and instruments in collecting data. The pre- test and post-test questionnaires were validated by the MAPEH Head Teacher who is a physical education major and two (2) Teachers III, all were from Sampaguita Village National High School in San Pedro District, Schools Division of Laguna. This gave an advantage within the limited time allotted for the completion of the study. The research instrument of the study was described below. The research instrument underwent two (2) types of validation, the face validation, and the content validation. For face validation of research instrument, a research-made questionnaire was submitted to a MAPEH Head Teacher and MAPEH Teachers critic who checked the overall format of the test questions to make sure that they would earn good impressions from the respondents and that they would not be confusing to the respondents and not lose their interest in answering seriously the test questions. Likert Scale was also used to determine the acceptability and effectiveness of MELC-Based Supplementary Learning Materials in Physical Education. The research instrument was submitted to individuals who were involved in instructional supervision over teachers. These individuals were school administrators. These experts scrutinized the research instrument for the purpose of checking whether the items in the research instrument were appropriate; to check whether the items were sufficiently specific and appropriate for each heading; and whether the items were relevant to the study and important for each heading.

\section{RESULTS AND DISCUSSION}

The data gathered on the given survey questionnaires whether the supplementary learning materials are effective or not and the data gathered from the given pretest and posttest to find out whether significant difference exists between the scores of the pretest and posttest after using the supplementary learning materials in physical education 9 .
Table 1. Level of Acceptability of the MELC-based Supplementary Learning Materials in terms of Content

\begin{tabular}{|c|c|c|c|}
\hline Statements & Mean & SD & $\begin{array}{c}\text { Verbal } \\
\text { Interpretation }\end{array}$ \\
\hline $\begin{array}{l}\text { All pictures, and } \\
\text { definition are } \\
\text { congruent to the } \\
\text { MELC- Budget of } \\
\text { Work for Physical } \\
\text { Education provided } \\
\text { by the DepEd } \\
\text { Region IV-A } \\
\text { CALABARZON }\end{array}$ & 4.38 & 0.52 & Strongly Agree \\
\hline $\begin{array}{l}\text { Contains topics that } \\
\text { are practically } \\
\text { related to each } \\
\text { other; }\end{array}$ & 4.18 & 0.48 & Agree \\
\hline $\begin{array}{l}\text { States objectives, } \\
\text { discussions and } \\
\text { activities that are } \\
\text { attainable; }\end{array}$ & 4.25 & 0.52 & Strongly Agree \\
\hline $\begin{array}{l}\text { Focuses on the } \\
\text { main goal which is } \\
\text { development of } \\
\text { learners and skills } \\
\text { in Physical } \\
\text { Education 9; }\end{array}$ & 4.33 & 0.64 & Strongly Agree \\
\hline $\begin{array}{l}\text { Are clearly stated } \\
\text { and can easily be } \\
\text { understood by the } \\
\text { students }\end{array}$ & 4.39 & 0.65 & Strongly Agree \\
\hline \multicolumn{4}{|c|}{$\begin{array}{l}\text { Overall Mean }=4.31 \\
\text { Standard Deviation }=0.572 \\
\text { Verbal Interpretation }=\text { Highly Acceptable }\end{array}$} \\
\hline
\end{tabular}

\section{Legend:}

$\begin{array}{llcc}\text { Scale } & \text { Range } & \text { Remarks } & \text { Verbal Interpretation } \\ 5 & 4.20-5.00 & \text { Strongly Agree } & \text { Highly Acceptable } \\ 4 & 3.40-4.19 & \text { Agree } & \text { Acceptable } \\ 3 & 2.60-3.39 & \text { Moderately Agree } & \text { Moderately Acceptable } \\ 2 & 1.80-2.59 & \text { Disagree } & \text { Less Acceptable } \\ 1 & 1.00-1.79 & \text { Strongly agree } & \text { Not Acceptable }\end{array}$

To highly acceptable, the respondents agreed that the supplementary learning materials were clearly stated and could easily be understood by the students with $(\mathrm{M}=4.39$, $\mathrm{SD}=0.65$ ) and all pictures, and definition are congruent to the MELC- Budget of Work for Physical Education provided by the DepEd Region IV-A CALABARZON with $(\mathrm{M}=4.38$, $\mathrm{SD}=0.52$ ). Although also observed be acceptable, the item with the lowest rating was "contains topics that are practically related to each other" with $(\mathrm{M}=4.18, \mathrm{SD}=0.48)$. The overall mean of 4.31, standard deviation of 0.572 indicated the level of acceptability of the MELC-based Supplementary Learning Materials in Terms of Content was highly acceptable. This meant that the supplementary learning materials contained significance in the study of the students. The number of 


\section{EPRA International Journal of Research and Development (IJRD)}

Volume: 6 | Issue: 6 | June 2021

- Peer Reviewed Journal

specified materials included in the supplementary learning materials was very practical.

Table 2. Level of Acceptability of the MELC-based Supplementary Learning Materials in Terms of Objectives

\begin{tabular}{|l|c|c|c|}
\hline \multicolumn{1}{|c|}{ Statements } & Mean & SD & $\begin{array}{c}\text { Verbal } \\
\text { Interpretation }\end{array}$ \\
\hline $\begin{array}{l}\text { Are clearly stated } \\
\text { and can easily be } \\
\text { understood by the } \\
\text { students; }\end{array}$ & 4.61 & 0.51 & Strongly Agree \\
\hline $\begin{array}{l}\text { Express the } \\
\text { knowledge and } \\
\text { skills to be } \\
\text { developed; }\end{array}$ & 4.51 & 0.52 & Strongly Agree \\
\hline $\begin{array}{l}\text { Are specific and } \\
\text { attainable; }\end{array}$ & 4.35 & 0.50 & Strongly Agree \\
\hline $\begin{array}{l}\text { Are based on the } \\
\text { Grade 9 MELC- } \\
\text { Budget of Work; }\end{array}$ & & 0.34 & Strongly Agree \\
\hline $\begin{array}{l}\text { Are related to the } \\
\text { discussion and } \\
\text { activities in the } \\
\text { worktext/ }\end{array}$ & & 0.41 & Strongly Agree \\
worksheet. & & \\
\hline $\begin{array}{l}\text { Overall Mean = 4.44 } \\
\text { Standard Deviation = 0.529 } \\
\text { Verbal Interpretation = Highly Acceptable }\end{array}$ \\
\hline
\end{tabular}

\section{Legend:}

$\begin{array}{llcr}\text { Scale } & \text { Range } & \text { Remarks } & \text { Verbal Interpretation } \\ 5 & 4.20-5.00 & \text { Strongly Agree } & \text { Highly Acceptable } \\ 4 & 3.40-4.19 & \text { Agree } & \text { Acceptable } \\ 3 & 2.60-3.39 & \text { Moderately Agree } & \text { Moderately Acceptable } \\ 2 & 1.80-2.59 & \text { Disagree } & \text { Less Acceptable } \\ 1 & 1.00-1.79 & \text { Strongly agree } & \text { Not Acceptable }\end{array}$

To highly acceptable, the respondents agreed that the supplementary learning materials were clearly stated and could easily be understood with $(\mathrm{M}=4.61, \mathrm{SD}=0.51)$ and expressed the knowledge and skills to be developed with $(\mathrm{M}=4.51, \mathrm{SD}=0.52)$. Although also observed to be highly acceptable, the item with the lowest rating was based on the Grade 9 MELC- Budget of Work with $(\mathrm{M}=4.33, \mathrm{SD}=0.54)$. The overall mean of 4.44 , standard deviation of 0.529 indicated the level of acceptability of the MELC-based Supplementary Learning Materials in Terms of Objectives was highly acceptable. This meant that the supplementary learning materials were not influenced by the personal feelings or opinions in considering and representing facts. The supplementary learning materials had achieved goal in expressing or dealing with the conditions as perceived without distortion by personal interpretations.
Table 3. Level of Acceptability of the MELC-based Supplementary Learning Materials in Terms of Topics

\begin{tabular}{|c|c|c|c|}
\hline Statements & Mean & SD & $\begin{array}{c}\text { Verbal } \\
\text { Interpretation }\end{array}$ \\
\hline $\begin{array}{l}\text { Are appropriate to } \\
\text { the students' } \\
\text { comprehension } \\
\text { level in physical } \\
\text { activities; }\end{array}$ & 4.31 & 0.48 & Strongly Agree \\
\hline $\begin{array}{l}\text { Are parallel with } \\
\text { the objectives and } \\
\text { activities; }\end{array}$ & 4.27 & 0.53 & Strongly Agree \\
\hline $\begin{array}{l}\text { Contribute to the } \\
\text { acquisition } \\
\text { concepts, } \\
\text { understanding } \\
\text { physical activities, } \\
\text { knowledge, } \\
\text { wellness and skills; }\end{array}$ & 4.22 & 0.41 & Strongly Agree \\
\hline $\begin{array}{l}\text { Provide a range of } \\
\text { learners' interests } \\
\text { and preferences; }\end{array}$ & 4.30 & 0.56 & Strongly Agree \\
\hline $\begin{array}{l}\text { Are sufficient to } \\
\text { allow the students } \\
\text { to learn } \\
\text { independently. }\end{array}$ & 4.28 & 0.51 & Strongly Agree \\
\hline \multicolumn{4}{|c|}{$\begin{array}{l}\text { Overall Mean }=4.28 \\
\text { Standard Deviation }=0.500 \\
\text { Verbal Internretation }=\mathbf{H i g h}\end{array}$} \\
\hline
\end{tabular}

\section{Legend:}

$\begin{array}{llcc}\text { Scale } & \text { Range } & \text { Remarks } & \text { Verbal Interpretation } \\ 5 & 4.20-5.00 & \text { Strongly Agree } & \text { Highly Acceptable } \\ 4 & 3.40-4.19 & \text { Agree } & \text { Acceptable } \\ 3 & 2.60-3.39 \text { Moderately Agree } & \text { Moderately Acceptable } \\ 2 & 1.80-2.59 & \text { Disagree } & \text { Less Acceptable } \\ 1 & 1.00-1.79 & \text { Strongly agree } & \text { Not Acceptable }\end{array}$

To highly acceptable, the respondents agreed that the module were appropriate to the students' comprehension level in physical activities with $(\mathrm{M}=4.31, \mathrm{SD}=0.48)$ and provided a range of learners' interests and preferences with $(\mathrm{M}=4.30$, $\mathrm{SD}=0.56$ ). Although also observed to highly acceptable, the item with the lowest rating was to contribute to the acquisition of concepts, understanding physical activities, knowledge, wellness and skills with $(\mathrm{M}=4.22, \mathrm{SD}=0.41)$. The overall mean of 4.28 , standard deviation of 0.500 indicated the level of acceptability of the MELC-based Supplementary Learning Materials in Terms of Topics was highly acceptable. This meant that the topics included in the supplementary learning materials were very timely. Its instructional objectives in three domain classifications were met. It involved factual, knowledge, ideas, and intellectual abilities. 


\section{EPRA International Journal of Research and Development (IJRD)}

Volume: 6 | Issue: 6 | June 2021

- Peer Reviewed Journal

Table 4. Level of Acceptability of the MELC-based Supplementary Learning Materials in Terms of Activities

\begin{tabular}{|l|l|l|l|}
\hline \multicolumn{1}{|c|}{ Statements } & Mean & SD & $\begin{array}{c}\text { Verbal } \\
\text { Interpretation }\end{array}$ \\
\hline $\begin{array}{l}\text { Are in order to } \\
\text { maintain the } \\
\text { students' interest in } \\
\text { each phase of the } \\
\text { learning material; }\end{array}$ & 4.31 & 0.50 & Strongly Agree \\
\hline $\begin{array}{l}\text { Provide a variety of } \\
\text { activities and } \\
\text { opportunities for } \\
\text { the improvement of } \\
\text { students' concept in } \\
\text { optimized wellness; }\end{array}$ & 4.23 & 0.46 & Strongly Agree \\
\hline $\begin{array}{l}\text { The exercises } \\
\text { stimulate students' } \\
\text { comprehension and } \\
\text { learning ability; in }\end{array}$ & 4.37 & 0.55 & Strongly Agree \\
\hline $\begin{array}{l}\text { Give direction in } \\
\text { simple } 4.44 \\
\text { comprehensible } \\
\text { manner; }\end{array}$ & 0.55 & Strongly Agree \\
\hline $\begin{array}{l}\text { Are relevant to the } \\
\text { expected outcomes } \\
\text { of objectives. }\end{array}$ & 4.43 & 0.50 & Strongly Agree \\
\hline $\begin{array}{l}\text { Overall Mean = 4.36 } \\
\text { Standard Deviation = 0.516 } \\
\text { Verbal Interpretation = Highly Acceptable }\end{array}$ & & \\
\hline
\end{tabular}

\section{Legend:}

\begin{tabular}{|c|c|c|c|}
\hline Scale & Range & Remarks & Verbal Interpretation \\
\hline 5 & $4.20-5.00$ & Strongly Agree & Highly Acceptable \\
\hline 4 & $3.40-4.19$ & Agree & Acceptable \\
\hline & $2.60-3.39$ & Moderately $\mathrm{A} \varepsilon$ & tely Acceptab \\
\hline & $1.80-2.59$ & Disagre€ & \\
\hline & $1.00-1.79$ & Strongly & agree \\
\hline
\end{tabular}

To highly acceptable, the respondents agreed that the supplementary learning materials gave direction in simple and comprehensible manner with $(\mathrm{M}=4.44, \mathrm{SD}=0.55)$ and were relevant to the expected outcomes or objectives with $(\mathrm{M}=4.43$, $\mathrm{SD}=0.50)$. Although also observed to highly acceptable, the item with the lowest rating was "provide a variety of activities and opportunities for the improvement of students' concept in optimized wellness" with $(\mathrm{M}=4.23, \mathrm{SD}=0.46)$. The overall mean of 4.36, standard deviation of 0.516 indicated the level of acceptability of the MELC-based Supplementary Learning Materials in Terms of Activities was highly acceptable. This meant that the activities included in the supplementary learning materials were effective in the type of learners under Modular Distance Learning (MDL).
Table 5. Mean Scores Performance of Students in Terms of Pretest

\begin{tabular}{|c|c|c|c|c|c|}
\hline Group & $\begin{array}{c}\text { Lowest } \\
\text { Score }\end{array}$ & $\begin{array}{c}\text { Highest } \\
\text { Score }\end{array}$ & Mean & $\begin{array}{c}\text { Standard } \\
\text { Deviation }\end{array}$ & $\begin{array}{c}\text { Verbal } \\
\text { Interpretation }\end{array}$ \\
\hline Emerald & 1 & 20 & 11.03 & 5.56 & $\begin{array}{c}\text { Fairly } \\
\text { Satisfactory }\end{array}$ \\
\hline Jade & 4 & 18 & 11.60 & 4.33 & Satisfactory \\
\hline Jasper & 2 & 18 & 10.33 & 4.32 & $\begin{array}{c}\text { Fairly } \\
\text { Satisfactory }\end{array}$ \\
\hline Sunstone & 2 & 16 & 9.53 & 4.01 & $\begin{array}{c}\text { Fairly } \\
\text { Satisfactory }\end{array}$ \\
\hline Overall & $\mathbf{1}$ & $\mathbf{2 0}$ & $\mathbf{1 0 . 6 2 5}$ & $\mathbf{4 . 6 0 2}$ & $\begin{array}{c}\text { Fairly } \\
\text { Satisfactory }\end{array}$ \\
\hline
\end{tabular}

Legend:

\section{Scale}

26 to 30

18 to 23

12 to 17

6 to 11

0 to 5

\author{
Verbal Interpretation \\ Outstanding \\ Very Satisfactory \\ Satisfactory \\ Fairly Satisfactory \\ Needs Improvement
}

Table 5 shows the mean scores performance of students in terms of pre-test. Out of 120 students, Jade received the highest $(\mathrm{M}=11.60, \mathrm{SD}=4.33)$ and verbally interpreted as Satisfactory, followed by Emerald with $(\mathrm{M}=11.03, \mathrm{SD}=5.56)$ and verbally interpreted as Fairly Satisfactory. While Jasper had $(\mathrm{M}=10.33, \mathrm{SD}=4.32)$ and verbally interpreted as Fairly Satisfactory. Sunstone received the lowest $(\mathrm{M}=9.53, \mathrm{SD}=4.01)$ and verbally interpreted as Fairly Satisfactory. With the weighted mean of 10.625 and supported value of standard deviation of 4.602 and the (Lowest Score $=1$, Highest Score $=$ $20)$ the mean scores performance of students in terms of pretest had a descriptive equivalent of Fairly Satisfactory.

Table 6. Mean Scores Performance of Students in Terms of Posttest

\begin{tabular}{|c|c|c|c|c|c|}
\hline Group & $\begin{array}{c}\text { Lowest } \\
\text { Score }\end{array}$ & $\begin{array}{c}\text { Highest } \\
\text { Score }\end{array}$ & Mean & $\begin{array}{c}\text { Standard } \\
\text { Deviation }\end{array}$ & $\begin{array}{c}\text { Verbal } \\
\text { Interpretation }\end{array}$ \\
\hline Emerald & 6 & 30 & 15.50 & 6.50 & Satisfactory \\
\hline Jade & 5 & 30 & 19.97 & 7.16 & $\begin{array}{c}\text { Very } \\
\text { Satisfactory }\end{array}$ \\
\hline Jasper & 7 & 30 & 16.87 & 7.47 & $\begin{array}{c}\text { Very } \\
\text { Satisfactory }\end{array}$ \\
\hline Sunstone & 5 & 30 & 14.80 & 7.07 & $\begin{array}{c}\text { Satisfactory } \\
\text { Overall }\end{array}$ \\
\hline $\mathbf{5}$ & $\mathbf{3 0}$ & $\mathbf{1 8 . 0 0}$ & $\mathbf{7 . 1 6 7}$ & $\begin{array}{c}\text { Very } \\
\text { Satisfactory }\end{array}$ \\
\hline
\end{tabular}

Legend:

Scale

26 to 30

18 to 23

12 to 17

6 to 11

0 to 5

\author{
Verbal Interpretation \\ Outstanding \\ Very Satisfactory \\ Satisfactory \\ Fairly Satisfactory \\ Needs Improvement
}

Table 6 shows the mean scores performance of students in terms of post-test. Out of 120 students, Jade received the highest $(\mathrm{M}=19.97, \mathrm{SD}=7.16)$ and verbally interpreted as Very 


\section{EPRA International Journal of Research and Development (IJRD)}

Satisfactory, followed by Jasper with $(\mathrm{M}=16.87, \mathrm{SD}=7.47)$ and verbally interpreted as Very Satisfactory. Moreover, Emerald got a $(\mathrm{M}=15.50, \mathrm{SD}=6.50)$ and verbally interpreted as Satisfactory. While Sunstone received the lowest $(\mathrm{M}=14.80, \mathrm{SD}=7.07)$ and verbally interpreted as Satisfactory. With the weighted mean of 18.00 and supported value of standard deviation of 7.167 and the (Lowest Score $=5$, Highest Score $=30$ ) the mean scores performance of students in terms of post-test had a descriptive equivalent of Very Satisfactory.

Table 7. Difference between Pre-test and Post-test Mean scores of Students using MELC-Based Supplementary Learning Materials

\begin{tabular}{|c|c|c|c|c|c|c|}
\hline \multirow{3}{*}{ Group } & \multirow{2}{*}{\multicolumn{2}{|c|}{ Mean }} & \multirow{3}{*}{$\begin{array}{l}\text { Mean } \\
\text { Differ } \\
\text { ence }\end{array}$} & \multirow{3}{*}{$\begin{array}{c}\text { t- } \\
\text { value }\end{array}$} & \multirow{3}{*}{$\begin{array}{c}\text { p- } \\
\text { value }\end{array}$} & \multirow{3}{*}{$\begin{array}{c}\text { Verbal } \\
\text { Interp } \\
\text { retatio } \\
\mathbf{n}\end{array}$} \\
\hline & & & & & & \\
\hline & $\begin{array}{l}\text { Pre- } \\
\text { test }\end{array}$ & $\begin{array}{c}\text { Post- } \\
\text { test }\end{array}$ & & & & \\
\hline Emerald & 11.03 & 14.30 & 3.30 & 16.732 & 0.000 & $\begin{array}{c}\text { Signific } \\
\text { ant }\end{array}$ \\
\hline Jade & 11.60 & 15.03 & 3.43 & 16.997 & 0.000 & $\begin{array}{c}\text { Signific } \\
\text { ant }\end{array}$ \\
\hline Jasper & 10.33 & 11.80 & 1.47 & 16.323 & 0.000 & $\begin{array}{c}\text { Signific } \\
\text { ant }\end{array}$ \\
\hline Sunstone & 9.53 & 14.47 & 4.94 & 26.876 & 0.000 & $\begin{array}{c}\text { Signific } \\
\text { ant }\end{array}$ \\
\hline
\end{tabular}

Table 7 presents the difference between pre-test and post-test mean scores of students using MELC-based Supplementary Learning Materials. The data were statistically treated using the t-test. The pretest was paired to the post test scores of students using Supplementary Learning Materials. The t-value of 7.4552 was greater than the critical t-value of 1.6557 and supported with p-value of 0.0000 . it could be inferred that there was an increase in the performance and the analysis was Significant. Based on the data, it was shown that there was a significant difference between pre-test and posttest mean scores of students using MELC-based Supplementary Learning Materials at 0.05 level of significance. It showed that the null hypothesis stating that "There is no significant difference between pre-test and posttest mean scores of students using MELC-based Supplementary Learning Materials" was rejected, it can be inferred that there is "significant" difference between them.

\section{CONCLUSIONS AND RECOMMENDATIONS}

The following were conclusions derived from the data and results of the study presented, analyzed, and interpreted: (1) The MELC-based Supplementary Learning Materials had very effective contents, objectives, topics, and activities; (2) The students showed improved achievement after using MELC-based Supplementary Learning Materials; and (3) The MELC-based Supplementary Learning Materials was an effective tool in teaching Physical Education during the new normal. There may be a lot of changes when it comes in teaching in this New Normal Set up of Education specifically in Physical Education. Based on the conclusions above, it is recommended that: (1) For students' better academic performance, MELC-based Supplementary Learning Materials can be used as alternative mode learning delivery for those who are not capable of having high end gadgets for modular distance learning. By using this students need not to go out of their houses, finding internet shops to search for the given activity, instead the answer are incorporated in the reading materials attached to the supplementary learning materials; (2) Teachers may adopt this MELC-based Supplementary Learning Materials in handling students under Modular Distance Learning (MDL); (3) For the School Administrators, they may provide allotted budget to produce this MELC-based Supplementary Learning Materials for students who are under Modular Distance Learning (MDL); (4) School Administrators may conduct seminars to assist teachers in making this kind of learning materials suited for each type of learners; and (5) For the Future Researcher, this study may help to improve the production of learning materials aligned in the New Normal Set Up of Education due to pandemic for Modular Distance Learning. Moreover, for the next researcher who will study this kind of research, it is necessary to validate together with the parents if the worksheet or activity sheets are solely answered by the students or respondents of the study.

\section{REFERENCES}

1. Abdu-Raheem, B.O. (2011). Availability, Adequacy, and Utilization of Social Studies Instructional Materials in Ekiti State Secondary Schools. Journal of Current Discourse and Research, pp. 242-255

2. Acero, V.O. et.al. (2012). Principles and Strategies of Teaching (2012 Edition), Rex Bookstore, Inc

3. Aguin, J., (2011). Teaching for Quality Learning at University (2nd Edition) The Society for Research into Higher Education Very Good Practical Handbook on Teaching.

4. Ajoke, A. (2017). The Importance of Instructional Materials in Teaching English as a Second Language

5. Banghero, M. (2015). "Validation and Effectiveness of Modular Learning Instruction in Literacy figures of Speech to Selected Literature Teacher in Don Manuel Rivera Memorial National High School Pila, Laguna" Unpublished Master's Thesis, Laguna State Polytechnic University, Main Campus, Santa Cruz Laguna.

6. Ball, D. (2018). Content Knowledge for Teaching What Makes It Special? School of Business Management, Ryerson University, 125 Victoria Street, Toronto, Ontario, Canada M5K $2 \mathrm{~K} 3$

7. Bucjac, M. (2011). Development and Validation of Modules in English 2: Writing in the Discipline, National Power Reviewed Journal, Vol. 6 ISSN2012 3981.

8. Bulusan, F. (2019). Selecting Potential Instructional Materials for Literature Teaching in the 21st Century Milieu: Findings from a Systematic Review of Literature

9. Bulusan, F. (2019). Facilitating Learner- Centered Teaching, Rex Book Store, pages 35; $42-43$

10. Capistrano, J.D. (2019). Innovative Instructional Delivery Package in Learning Science among Grade 9 Students. Unpublished Master's Thesis, Laguna State Polytechnic University, Sta, Cruz, Laguna.

11. Dahar, M. (2011). Effect of the Availability and the Use of Instructional Material on Academic Performance of Students in Punjab Pakistan. Euro Journal Publishing Inc. 


\section{EPRA International Journal of Research and Development (IJRD)

12. Danielson, C. (2017). Enhancing Practice: A Framework for Alexandria, VA; Association for Curriculum Development

13. Everette, M. (2017). The Hidden Power of Learning Objectives. College Press 123-4 Amsterdam Avenue, New York, NY 10027. Museum of Science.

14. Hale, D. (2018). Why it is Important to Pretest the Questionnaire?

15. Ibeneme, O.T. (2000). Provision and Utilization of Instructional Equipment for Teaching and Learning Science and Technology. Issues in Educational Journal, 1, 139-144.

19. Malik, T. (2019). Comparative Analysis between PreTest/Post-Test Model and Post-Test-Only Model in Achieving the Learning Outcomes

20. McTighe, J. \& Guskey, T. (2016). Pre-Assessments: Promises and Cautions https://tguskey.com/wpcontent/uploads/Article-15-Guskey-PreAssessment.pdf.

21. Nic, O, (2013). Why Learning Objectives is so Important? http://www.aic.lv/ace/acedisk/Bologna/contrib/ESIB/QAhandbook.pdf.

22. Olayinka, A.R.B. (2016). Effects of Instructional Materials on Secondary Schools Students' Academic Achievement in Social Studies in Ekiti State, Nigeria. World Journal of Education, $p .32$

23. Orosco, R. (2020). Infographics: An Alternative Assessment Strategy to Improve Students' Academic Performance in Chemistry Unpublished Master 's Thesis, Laguna State Polytechnic University, main Campus, Santa Cruz, Laguna. pp. 76-80.

24. Secton, M. et. al., (2017). Acceptability of Healthcare Interventions: An Overviews and Development of a Theoretical Framework. BMC Health Services Research BMC series- open, Inclusive and Trusted 2017.

25. Shivaraju, P.T., Manu, G. \& Savkar, Vinaya, M. \& Savkar, M. (2017). Evaluating the Effectiveness of PreTest and Post-Test Model of Learning in a Medical School

26. Taip, E. (2018). Acceptability of Validated Supplementary Learning Material in Physical Education Unpublished Master's Thesis, Laguna State Polytechnic University, Sta. Cruz, Laguna.
16. Ikerionwu, J.C. (2000). Importance of Aids and Resources in Classroom Teaching. In A.M.Oyeneyin (Ed.), Perspective of Classroom Teaching. Abuja: Martmonic Investment Ltd.

17. Lucas, M.R. \& Corpuz, B. (2013). Facilitating Learning: A Metacognitive Process, Lorimar Publisher pages 95- 99; 143-146.

18. Majault, J. (2015). Posttest Subsequent to Teachers' Instructional Style. Connecticut: District Educational Brochure. 